\title{
An Islamic Perspective on Self-Reliance Economy
}

\author{
Rozikan $^{1, *}$ Mukhlis Rahmanto ${ }^{2}$ Julia N. E. Satyarini ${ }^{3}$ \\ ${ }^{1}$ Faculty of Islamic Study, Universitas Muhammadiyah Yogyakarta, Yogyakarta, Indonesia \\ ${ }^{2}$ Faculty of Islamic Study, Universitas Muhammadiyah Yogyakarta, Yogyakarta, Indonesia \\ Faculty of Islamic Study, Universitas Muhammadiyah Yogyakarta, Yogyakarta, Indonesia \\ *Email:Rozikan.fai@umy.ac.id
}

\begin{abstract}
This article aims to discover the Islamic normative teachings of self-reliance economy. Does it stand alone as a concept or become an integral part of other major concepts in Islam. This issue is important because, from an economic standpoint, most of the countries with a majority Muslim population are in the category of underdevelopment and dependent on other countries, for example, in terms of foreign debt. This raises significant questions with like, which is the concept of independence in Islam itself and its historicity. The reflective normative deductive approach is used to examine both sources of Islamic teachings. Some findings are a. Economic independence in Islam is not a separate standalone concept, but it is related to other major themes in Islam, such as development, ummah, and other institutional structures; $b$. Economic independence in Islam is not the culmination of an independent building because the most important is the spiritual independence.
\end{abstract}

Keywords: Self-Reliance, Economy Islamic Perspective, Independence

\section{INTRODUCTION}

Islam teaches in its various normative teachings to guide human life in all its life aspects, including the economy. When compared with other religions, Islam gives more attention in terms of economics [21]. The main objective is the distribution of economic resources evenly so that welfare can be felt by everyone. The Qur'an and the Hadith, as both sources of religious ethics about the economy, provide a paradigm as well as practical tools for realizing this objective and starting from the theory of ownership that is equipped with antiusury devices, to the orders of almsgiving and philanthropy. Among the economics topics mentioned by the Qur'an is the economic independence of the ummah as one of several frameworks that forming the concept of ummah [5].

Meanwhile, in the history of economic thought, the discussion of economic independence has been motivated by many issues. First, the issue of the economic and financial crisis as reflected in the writings of Ralp Waldo Emerson in which he campaigned for a self-reliance movement when America in 1837 experienced a severe economic crisis due to dependence on an external supply of gold and British investment, also domestic problems where prices skyrocketed and flooded unemployment. Self-reliance meant by Ralp Waldo Emerson (1841) is an individual's authority to determine one's own destiny, not dependent on the government to other authorities such as the religious authority [13]. If seen it opinion from an Islamic perspective is part of secularism and becomes the root of liberal capitalism, which is based on the market. Furthermore, self- reliance becomes a kind of American way of life, along with liberty and individuality [8]. The second issue is the contest for achieving economic progress between developed, developing and underdeveloped countries, such as the case of China in the late 1970s, which allowed external assistance as a subsidiary, which previously emphasized inward-looking during the Mao Zedong era [6]. Decades later, China's success can be seen in its affluence by surpassing America as the crown holder of the world economy. The case of China influenced the concept development of self-reliance that cannot be separated from external support. This means that the second issue affects the third issue in which the concept of economic independence was born from the theory of dependence (dependency) that began in Latin America, which depends on the United States economy. The United States, as a developed industrial country, requires a lot of raw materials that Latin American countries have. This is where the dependency scheme emerges as the Chilean economist Theotonio dos Santos reads it [19]. 
This dependence is caused by the expansion of capitalism, which results in economic growth on the one hand and backwardness on the other side. From this point, it can be interpreted that the economic independence of a nation when it freed from capitalism that gave rise to domination and exploitation. It is possible in today's context where capitalism is an unavoidable historical fact. Even socialism is almost extinct, if not already dressed in capitalism, as modern China nowadays. Therefore, political economy strategies emerge to minimize this dependency, one of which is export-led industrialization carried out by developing countries [17].

The facts of economic history above indicate that the term economic independence is not as simple as its semantics by only relying on oneself (i.e., individual, household, market, community, and country). But it involves many agents in a very complex modern society that, at first glance, disclaims self-sufficient itself as well as being used as an approach in certain studies, for example in the economic and political area.

Thus an integrated approach is needed in reading the concept of economic independence, ranging from philosophy, socio anthropology, psychology, semantic to religion. Philosophically, the issue of economic independence begins with a discussion about human actions, whether free will or determinism, which forms the discursive tradition of America that gave rise to freemarket behavior. In terms of socio- anthropology, especially human existence itself, independence can be seen from the biological and physiological forms that indicate a dependence on others and become a universal phenomenon and experience, in contrast to economic, psychological, and emotional factors which depend on a particular context [12]. Meanwhile, in the American tradition, humans are seen as a resource that must be maximized by full employment. Americans typically hold that everyone who is physically and mentally able to work should absolutely do so; they treat this economicbased self-sufficiency as a moral ontological reality and obligation [8].

Semantically, the word "independence" is synonymous with other words with like autonomy, independent, self-reliance, and self-sufficient (adjective), which is associated with the ability to produce something without the help of others [7]. More deeply, the word independence is closely related to self-dependence on others, while autonomy is more directed to the decisionmaking part. Furthermore, in the past few decades, the word independence is used as an approach and is identical to the economic production in the macro sphere with the state as the culprit. Actually, there is a diction for economic independence, namely autarchy, but it is more directed to the economic position of a country that is closed and out of international trade [4]. Therefore, the word self-sufficiency economy is more appropriately known as economic independence because it is still based on the nature of impossibility in sufficiency.

From a religious perspective, independence is emphasized by all religions, including Islam, that has normative teachings of economic ethics. Economic independence becomes an important part of the discussion in the scope of socio-political ties, namely ummah, with global scope and crossing national borders. This article aims to discover the normative teachings of Islam in the Qur'an and the Hadith regarding the concept of economic independence and its historicity. The approach used is normative deductive reflective, which, according to [16], this deductive method is considered representative in generating knowledge. Previous studies conducted by scholars such as

[5] Opines that self-sufficiency in the economy is something impossible in today's global economic order. Meanwhile, [9] places more emphasis on the Islamic concept of self-reliance for poverty alleviation by a method of balancing income and expenditure. [14, 3] studies about Khursid Ahmad's self-reliance concept, which is associated with Islamic economics based on usury as a system that reflects the independence of the economic system and solutive to existing economic systems. Meanwhile, [2] Studied economic independence in the Qur'an by emphasizing their praxis on the three Islamic sharia frameworks, namely zakah (Islamic almsgiving), hajj (Islamic pilgrimage) and jihad. Based on the previous work, further discussion is needed to develop a study of economic independence in Islam that has been empirically carried out by ethnographic studies by [10] in the Hui Minjian community in Northwestern China were politically and economically independent with funding support from Islamic charity in the midst of an uncertain political situation. These studies still deny the existence of a structure capable of building self-reliance, including Muslims themselves.

\section{SELF-RELIANCE ECONOMY IN ISLAMIC TEACHINGS AND IT IS CONTEXTUALIZATION}

The term economic independence in Arabic as the language of Islamic normative teachings is translated by Arab economists as "al-iktifa al-dzatiy al-iqtishady" as an equivalent of autarchy in English. When the word "aliktifa al-dzatiy" can be guessed to refer to individual independence (sufficiency and self-satisfaction) in terms of economic (al- iqtishady). It means "al-dzatiy" can be seen and developed from the perspective of structuralism that can involve the level of family, society, market, state, and ummah. Meanwhile, Khurshid Ahmad defines selfsufficiency or self-reliance economy as the significance of the capacity and capability of the country to face any crisis on the basis of internal strength. It implies self- 
confidence and the capacity for autonomous goal-setting and decision-making, rejecting all forms of dependence, invited or imposed. In this case, Khurshid Ahmad directly brings the context of independence at the country level, whereas economic independence itself is the accumulation of the economic independence of the nation's individuals. The definition is almost in line with what was stated by [15] that self-reliance is the meaning of autonomy of decision-making and full mobilization of a society's own resources under its own initiative and direction. But the emphasis is more on society than the state. Martha Albertson [12] places more emphasis on the family level because the family is a robust collection of autonomy consisting of individuals, including women, who will strengthen the state autonomy. In my opinion, before family, society, and country, it must start from the smallest micro-scope of individuals.

When individuals are the basis for realizing independence, the Qur'an and the Hadith teach the doctrine of economic education, which carries a broader mission of the goals of human, social, and political development in Islam. Individual framework related to independence described by the Qur'an consists of four things, including:

a. Humans naturally in Islam, apart from the debate of many schools, in principle, have the nature of freedom and independence to determine what they want to do, good or bad. But his choice was limited by the rules (Shari'a) of God, which aims to safeguard human welfare. Therefore, homo economicus relies only on rational principles in economic behavior (production and consumption) cannot be justified in the Islamic view. This is based on several teachings of the Qur'an:

"And that there is not for man except that [good] for which he strives" (Al-Qur'an: An-Najm: 39)

"And inspired it [with discernment of] its wickedness and its righteousness" (Al-Qur'an: As-Shams: 8) "Every soul, for what it has earned, will be retained" (Al-Qur'an: Al-Mudatsir: 38)

"Say," Each works according to his manner, but your Lord is the most knowledgeable of who is the best guided in the way. " (Al-Qur'an: Al-Isra ': 84)

b. Economics independence is identical and represents the fulfillment of human material needs, such as food, housing, transportation, health, and children's education. But in Islam, the condition of economic independence in this form does not become the peak of independence. The peak of an individual's independence when he is in a condition, which is described by the Prophet's hadith as "rich and sufficient soul", that one's soul is said to be independent if it is no longer limited by material desires. He felt sufficient and independent of his condition. This means that independence is wrapped with economic ethics, namely qana'ah. Qana'ah is a condition of being satisfied with what is given by God [1]. The Prophet's saying:

"Abu Hurairah (May Allah be pleased with him) reported: The Prophet peace be upon him said," Richness is not the abundance of wealth, rather it is self-sufficiency "(Al-Bukhari)

At first glance, the concept of "rich and pretty soulghina al-nafs" is contrary to the concept of independence itself because it teaches surrenderd and makes human an agent who deny free agency. Still, Islam emphasizes the balance of life between here and hereafter, which has an impact on the balance of material and spiritual independence. In a metaphysical transcendental, this form of spiritual independence is an awareness and its location in the heart.

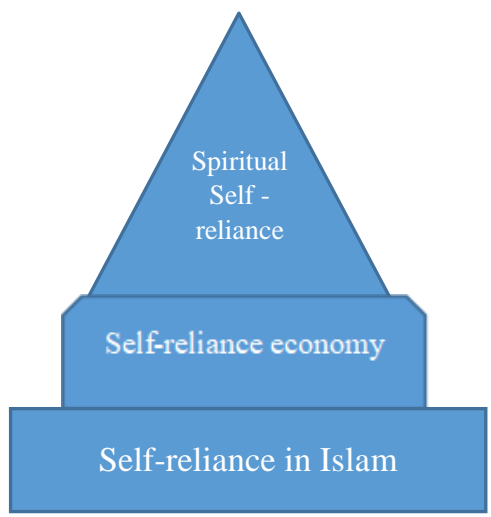

Graphic 1. Self-reliance in Islam

Source: self-reflection inspired by Maslow's pyramid hierarchy of needs

c. Work is an Islamic command to make a person have material independence while achieving, spiritual independence (ghina al-nafs). That is, working as a profane concept in Islam has a sacred value. After a person attains material independence, Islamic economic ethics teaches to distribute that independence to others who have not yet reached these conditions in order to achieve and have the same conditions of independence as the donor of independence. That is, through charity infaq, waqf and other Islamic gifts become a means provided by Islam to realize economic and spiritual independence. Quranic verses and the Hadith that teaches work are:

"And say, Do [as you will], for Allah will see your deeds, and [so, will] His Messenger and the believers. And you will be returned to the Knower of the unseen and the witnessed, and He will inform you of what you used to do. " (Al-Qur'an, At-Taubah: 105)

"Narrated Az-Zubayr ibn Al-Awwam: The Prophet, peace be upon him said, "It is better for anyone of you 
to take a rope (and cut) and bring a bundle of wood (from the forest) over his back and sell it, and Allah will save his face (from the Hell-Fire) because of that, rather than to ask the people who may give him or not. " (Al-Bukhari)

Economic independence in Islam is based on the principle of "sufficient economics" with six indicators of primary needs in the main objectives of the sharia maqashid general objectives that can be developed to meet the needs of tahsiniyat. So there is a leveling and priority of independence, starting from primary, secondary, and tertiary. The values of maqashid are based on the upholding of goodness, and the prevention of badness which is derived from the concept of "mercy" as the main goal of the Prophet Muhammad sent to the world

"And we have not sent you, [O Muhammad], except as a mercy to the worlds" (Al-Qur'an, Al-Anbiya ': 107)

The constituent elements of individual independence above can be placed in a more macro context, such as society, market, and country, or in the context of supramacro Islam is ummah. Here the normative values of Islam make historization.

At the state level, where the representation and accumulation of independence lie with the government, it is must realize and protect the independence of individuals- people based on the principle of maslaha (public interest) and the common good, where these two principles are universal symptoms. How does the state apart from debates whether it must be an Islamic state symbolically or substantially - must be independent to meet the needs of its people in many sectors. This independence is needed so that when an economic crisis occurs, a country can survive other than to achieve the sovereignty of a nation. The problem is when there is a fact of dependency in terms of trade, finance, and technology of a country with other countries. Between the West, which is categorized as developed countries, especially it is the industrial sector, with developing countries as a continuation of colonialism. This condition covered most of the Muslim majority countries. Therefore we need a strategy of economic independence in particular, for example, with labor-intensive industries that produce goods for mass needs and open up employment opportunities and income for many people. A strategy that although it cannot be separated from other countries' investment, there is a transfer of technology and capital accumulation in term of minimizing the dependency.

When economic independence is cultivated, spiritual independence is also sought. Or the second condition will accompany it. Even both can play each other's roles, respectively. When economic independence is empty of spiritual content, there will be a drought in the inner dimension of man as experienced by modern western society (Nasr, 1990). Conversely, if only seek spiritual independence, there will be fatalism and life destruction, especially when the earth as God's gift is not prospered. Whereas normatively, Allah teaches in the Qur'an AlAnbiya ': 70: "And We have certainly honored the children of Adam and carried them on land and sea and provided for them of the good things and preferred them over much of what We have created, with [definite] preference."

At the level of ummah as a concept of a global Islamic society, economic independence is based on consciousness and solidarity of faith, especially in the Qur'an, Al-Hujurat: 10: "The believers are but brothers, so make settlement between your brothers. And fear Allah that you may receive mercy". In this case, look at the contribution of classical Muslim thinkers and economists, this solidarity is structured by Ibn Khaldun in the concept of ashabiyah. Although Ibn Khaldun was referring to [asabiyyah within the area of ruled by a particular political authority, this need not necessarily have been the result of any conceptual limitation on his part. It was perhaps due to the availability of limited transportation and communications facilities at that time. With the advanced communications and technology of modern times, the concept of asabiyyah should be understood to stand for solidarity between all the nations of the world and the integration of their economies and societies in keeping with the Islamic goals of human brotherhood. If mutual cooperation and dependence can promote development in a region, why not in the world as a whole [5].

The awareness and solidarity have an impact on efforts to realize economic independence, in the context of which was the establishment of the Islamic Development Bank (IsDB) by the Organization of Islamic Countries (OIC) to help each other in financing development. IsDB has a vital role in supporting the independence of the OIC economy by reducing foreign debt dependence with other financing institutions that offer interest-based financing schemes and offer specific missions behind the disbursed loans. Therefore, the country given credit becomes dependent not only financially, but also its political economy. In addition, IsDB plays a necessary war by making the Islamic economic system as an alternative solution to the current financial system. This means that IsDB plays a role in realizing the independence of the economic system in accordance with the values and basic principles of Islam in the midst of an increasingly globalized world and the dominance of a liberal capitalist economic system. The strength of the independence of ummah created a separate market as happened in the economic history of Muslims in Medina when the Prophet founded his own market because the existing market has been reluctant to accept Muslim traders and operate with a system that is contrary to Islamic principles. 
This does not then indicate that Islam is isolating itself from the competition of global civilization. The establishment of a separate market still opens opportunities for economic actors to contribute to this market in terms of they follow the system used in the market. Al-Qur'an and the saying of the Prophet never taught restrictions on the scope of the economy as part of muamalah with certain ethnic, racial, and religious factors because muamalah is part of the universal order. The establishment of a separate market by the Prophet in Medina can be interpreted in the context of fastabiq alkhairat (competing in goodness) in a plural economic market.

\section{CONCLUSION}

To sum up, self-reliance economy in an Islamic perspective cannot be separated from the concept and purpose of development in Islam that does not separate material and spiritual dimensions, between the sacred and the profane. Therefore, this article offers a new understanding that above economic independence, which has been the main goal of individuals also a country, the fact in Islamic teachings, hierarchically, its position is not the top of independence, but one level below from spiritual independence (ghina ' al-nafs). Both manifestations of independence can be done through the maqashid sharia approach, which is based on a hierarchy of needs.

\section{REFERENCES}

[1] Ali, Mohammed Farid. (2014) Contentment (Qanā'ah) and Its Role in Curbing Social and Environmental Problems. Islam and Civilisational Renewal IAIS, Vol. 5, no. 3, p. 433.

[2] Al-Mazhahiri, Muhammad Amir. (no year) Mabda' al- Iktifa al-Iqtishadiy fi ba'dhi al-Ahkam alQur'aniyyah. Majalah al-Jami'ah al-Islamiyah, vol. 148, p. 61.

[3] Bhat, Nasir Nabi. (2016) The Economic Thought of Khurshid Ahmad, Turkish Journal of Islamic Economics, Vol. 3, No. 2, pp. 7-8

[4] Bondarenko, Peter. (2010) Autarky (economics) entry in Encyclopaedia Britannica,

15 th edition,

https://www.britannica.com/topic/autarky

[5] Chapra, M. Umer. (2001) Islamic Economic Thought and the New Global Economy. Islamic Economic Studies, Vol. 9, No. 1, 7.

[6] Chen, Chien-Hsun. (1992) Modernization in Mainland China: Self-Reliance and Dependence, The American Journal of Economics and Sociology, Vol. 51, No. 1, 59-61.
[7] Christ, G. Elgie (ed.), (2012) Dictionary of English Synonyms \& Antonyms. Selangor: Thinkers Library, p. 28, 272.

[8] Daugherty, Robert H. and Gerard M. Barber. (2001) Self - Sufficiency, Ecology of Work, and Welfare Reform. Social Service Review, Vol. 75, No. 4, 664.

[9] Dogarawa, Ahmad Bello. (2006) Combating poverty through self-reliance: The Islamic approach. Munich Personal RePEc Archive, No. 23139, pp. 8-14

[10] Erie, Matthew S.(2016) Sharia, Charity, and Minjian Autonomy in Muslim China: Gift giving in a plural world. American Ethnologist, Vol. 43, No. 2, pp. 321-323

[11] Fineman, Martha Albertson. (2004) The Autonomy Myth: A Theory of Dependency. New York: The New Press, pp. 104- 105.

[12] Fineman, Martha Albertson. (2013) Cracking the Foundational Myths: Independence, Autonomy, and Self-Sufficiency, The American University journal of gender, social policy \& the law, vol. 8, p.15.

[13] Hacht, Anne Marie. (2007) Literary Themes for Students: The American Dream, Vol. 1. Michigan: Gale, 453- 466.

[14] Hassan, Mehboob Ul. (2010) Islamic Approach of Economics: Some Discourses on Khurshid Ahmad's Vision of Socio-Economic Order, Self-Reliance and Economic Development. Kyoto Bulletin of Islamic Area Studies, 3-2, pp. 230-232.

[15] Hope, Kempe Harold. (1983) Self Reliance and Participation of the Poor in the development process in the Third World, Future, pp. 455-457.

Nasr, Sayyed Hossein. (1990) Man and Nature The Spiritual Crisis of Modern Man. London: Mandala Unwin Paperbacks, pp. 17-19.

[16] Popper, Karl. (2005) The Logic of Scientific Discovery.

London: Routledge, pp.9-11.

[17] Rahardjo, Muhammad Dawam. (2003) Kemandirian Ekonomi Untuk Menegakkan Kedaulatan Bangsa, paper presented in Seminar Pra Tanwir Muhammadiyah June 2003, Jakarta, p.10.

[18] Sadeq, AbulHasan M. (1996) Ethico-Economic Institution of Zakah: An Instrument of Self-Reliance and Sustainable Grassroot Development. Humanomics, Vol. 12 Iss 2, p.52-56.

[19] Santos, Theotonio Dos. (1970) The Structure of Dependence. The American Economic Review, Vol. 60, No. 2, p. 231, 234. 
[20] Tarling, Roger and Frank Wilkinson. (2003) Economic functioning, self-sufficiency and full employment, in Systems of Production Markets, Organisations and Performance edited by Brendan Burchell, Simon Deakin, Jonathan Michie and Jill Rubery, London: Routledge, 2003, p. 214.

[21] Wilson, Rodney. (1997) Economics, Ethics and Religion: Jewish, Christian and Muslim Economic Thought. New York: New York University Press 